\title{
Decreasing greenhouse effect in agriculture using biodiesel - when green may be enough
}

\author{
F. Coppola, M. Bravi, R. Ridolfi \& E. Tiezzi \\ Department of Chemical and Biosystems Sciences, \\ Siena University, Italy
}

\begin{abstract}
In the last decade a great number of studies have been carried out on the possible use of biofuels in order to reduce greenhouse gas emissions. Among biofuels, biodiesel has gained considerable attention as the need to develop alternatives to traditional diesel fuel increases. The Italian parliament adopted directive 2003/30/CE from the European Parliament, in which the guidelines about future production and consumption of biofuels are reported: $1 \%$ and $2.5 \%$ of biofuels within 2005 and 2010 respectively. The aim of this work is to investigate the reduction in greenhouse gas emission obtained by using biodiesel in agricultural practises, and the role of renewable energy use at a local scale. Comparison between diesel and sunflower methyl ester was made from the point of view of an emission inventory, from production and combustion, by using different scientific tools, such as IPCC methodology and the Danish Life Cycle Assessment (LCA) EDIP Database. Results show that the use of sunflower methyl ester, other than the renewability of $\mathrm{CO}_{2}$ emitted, implies a general reduction of $\mathrm{CO}_{2}$ equivalent emissions of up to $57 \%$.

Keywords: biodiesel, sunflower, renewability, GHG, catalysts, $\mathrm{CO}_{2}$ equivalent.
\end{abstract}

\section{Introduction}

In this paper we address the increasing need for environmental safeguards concerning the production of energy. Fossil fuels used every day are not environmental friendly. Therefore, we arrive at the question: "is it possible to produce fuels for antrophic needs and respect the environment?" From this point of view biofuels could bring ecological advantages with good energy efficiency and a certain degree of sustainability [2]. Among biofuels, biodiesel, a fuel that 
can be made from renewable biological sources such as vegetable oils or animal fats, has been recognized as an alternative fuel to substitute conventional fuel, for diesel engines. From an ecological point of view there is ecotoxicological evidence about the properties of biodiesel, like the low resistance to microorganisms biodegradation and biotransformation with respect to fossil diesel as reported by other studies [3, 4]. Biodiesel is produced by using crop productions like rapeseed, soy, sunflower, but also from some species of marine algae [5, 6,]. Although the first diesel cycle engine invented by Rudolf Diesel ran on peanut oil [7], with the increase of fossil fuels production, conventional diesel became the only fuel used. The consumption of $3.8 \times 10^{12} \mathrm{~kg}$ per year of fossil fuels [8], developed great influence on atmospheric dynamics and global climate change. About $2.54 \times 10^{13} \mathrm{~kg}$ of $\mathrm{CO}_{2}$ are added to the atmosphere annually [9]. At the moment it is impossible to substitute diesel fuel with biodiesel absolutely. However, there is the possibility of using biodiesel in the agriculture compartment in order to reduce green house gases emission, and moreover to reduce the agricultural industries' dependence on fossil energy. The aim of this study is to demonstrate, by using pure biodiesel (BD 100), the possible emissions and land use scenarios from a simulation of a farm system of Siena province, Italy.

\section{Methods}

We tested the effective reduction in green house gases emissions, using biodiesel fuel from sunflower cultivation, from its oil seed transesterification, and from its final combustion. We will also evaluate the level of sustainability of the entire process, from the point of view of land requirement and the renewability of $\mathrm{CO}_{2}$ emissions. The inventory of emission refers to the following gases: Carbon dioxide $\left(\mathrm{CO}_{2}\right)$, Nitrous oxide $\left(\mathrm{N}_{2} \mathrm{O}\right)$, Methane $\left(\mathrm{CH}_{4}\right)$.

The simulation shows three possible steps; each of them has its own weight in emissions dynamics.

- Step $a$, in which we start to quantify the fossil diesel used and the related emissions in a typical Tuscan farm for wine production; here we have selected a representative farm system;.

- Step $b$ in which we calculate the amount of biodiesel production required (agricultural phase) to replace fossil diesel: the land use for sunflower production, fossil fuel required and related emissions. Here we have selected a typical farm system (1000 ha) for sunflower cultivation.

- Step c in which we consider the farm system self sufficient for wine and biodiesel production, using biodiesel fuel only, (agricultural and industrial phase) and related emissions.

Our simulations are based on different data set:

- diesel fuel quantities for wine and sunflower production are obtained from field data collection, in which the diesel fuel consumption for each field operation is reported; 
- emissions of diesel fuel production are based on data obtained from the Danish Life Cycle Assessment (LCA) EDIP Database [10];

- emissions of diesel fuel combustion are calculated by using IPCC methodology-module Energy [11];

- $\quad$ emissions of biodiesel agricultural production are calculated by using IPCC methodology-module Agriculture [11];

- $\quad$ emissions of biodiesel industrial production are calculated by using data from the EU Biofit project [12];

- $\quad$ emissions of biodiesel combustion are calculated from the results of the EPA Biodiesel Emissions Database [13].

\section{Results}

\subsection{Step a.}

As mentioned previously, the first step is to investigate diesel fuel consumption in a local vineyard. Data collected refers to a consumption estimated at $658 \mathrm{~kg}$ $\mathrm{ha}^{-1}$ year $^{-1}$ for field operations. First of all we have calculated emissions from diesel fuel production. We used data from the Danish Life Cycle Assessment (LCA) EDIP Database, in which all raw material input for each operation and related gas emission output for each $1 \mathrm{~kg}$ of diesel fuel produced is reported. The second step was to calculate emissions from diesel fuel combustion, using IPCC methodology, Module 1 Energy. In Table 1 the emissions related to the total diesel fuel quantities used in the vineyard. By multiplying this result for Global Warming Potential (GWP) of methane and nitrous oxide we obtained the total $\mathrm{CO}_{2}$ equivalent emissions (Table 2).

Table 1: $\quad$ Emissions from total diesel fuel consumption $(658 \mathrm{~kg})$.

\begin{tabular}{|c|c|c|c|}
\hline & Diesel production & Diesel combustion & Total diesel use \\
\hline $\mathbf{C O}_{\mathbf{2}}$ & $3.02 \mathrm{E}+02$ & $2.09 \mathrm{E}+03$ & $2.39 \mathrm{E}+03$ \\
\hline $\mathbf{C H}_{\mathbf{4}}$ & $2.82 \mathrm{E}+00$ & $1.43 \mathrm{E}-01$ & $2.96 \mathrm{E}+00$ \\
\hline $\mathbf{N}_{\mathbf{2}} \mathbf{O}$ & $7.63 \mathrm{E}-03$ & $1.71 \mathrm{E}-02$ & $2.47 \mathrm{E}-02$ \\
\hline
\end{tabular}

Table 2: $\quad$ Total carbon dioxide (CO2) emissions $(\mathrm{kg})$ from diesel use.

\begin{tabular}{|c|c|c|}
\hline GHG & GWP & $\mathbf{C O}_{\mathbf{2}}$ equivalent \\
\hline $\mathbf{C O}_{\mathbf{2}}$ & 1 & $2.39 \mathrm{E}+03$ \\
\hline $\mathbf{C H}_{\mathbf{4}}$ & 21 & $6.82 \mathrm{E}+01$ \\
\hline $\mathbf{N}_{\mathbf{2}} \mathbf{O}$ & 310 & $7.32 \mathrm{E}+00$ \\
\hline \multicolumn{2}{|c|}{ Total $\mathbf{C O}_{\mathbf{2}}$ equivalent } & $2.47 \mathrm{E}+03$ \\
\hline
\end{tabular}




\subsection{Step b.}

Before illustrating step $b$ we have to introduce a new parameter to calculate the amount of biodiesel production that depends on sunflower oil-seed yield. Emissions from the "biodiesel system" depend on the amount of land used for its production; from this point of view the higher the industrial transformation yield, the lower land use and related emissions. To remark this concept for our simulation, we refer to the study conduced by Vicente et al. [14] in which a comparison is made between different basic catalysts for methanolysis of sunflower oil, in transesterification process. The catalysts are sodium hydroxide, potassium hydroxide, sodium methoxide, potassium methoxide and each catalyst has a specific biodiesel yield $(\mathrm{wt} \%)$ in the transformation process as follows: $86.71 \%, 91.67 \%, 99.33 \%, 98.46 \%$, respectively. The amount of biodiesel necessary to substitute diesel used for vineyard field operations was calculated by using the comparison of the net calorific value of the two fuels; since biodiesel has lower net calorific value than diesel, $756 \mathrm{~kg}$ of biodiesel was required to replace $658 \mathrm{~kg}$ of diesel. According to previous methodology explications, data about diesel consumption necessary to sunflower cultivation came from a 1000 ha area of cultivated farmland, and the sum of all diesel consumptions of field operations is $108 \mathrm{~kg}$. From field data and statistical data collected [15], sunflower seed yield was estimated to vary between 1500 and $2500 \mathrm{~kg} \mathrm{ha}^{-1}$; Kallivroussis et al. [16] reports the yield of raw oil output from the seed crushing process is fixed at $32-38 \%$. To calculate the yield of biodiesel we assumed a value of $2000 \mathrm{~kg}$ of sunflower seeds with a yield in the transesterification process fixed in $35 \%$ (Table 3). Another important variable is the fertilizer input necessary for sunflower cultivation. From field data we reported the quantity of nitrogen fertilizer to be fixed at $200 \mathrm{~kg} \mathrm{ha}{ }^{1}$. At this point we were able to calculate the amount of land use, fertilizer input, diesel fuel consumption, all related to the yield of different catalysts used, and related emissions. In Table 4 we reported land use, fertilizer and diesel consumption necessary to biodiesel production referred to two fixed values, sunflower seed yield, and oilseed yield, $2000 \mathrm{~kg}$ and $35 \%$ respectively.

Table 3: $\quad$ Biodiesel yield, $\mathrm{kg} \mathrm{ha}^{-1}$ related to different catalysts.

\begin{tabular}{|c|c|c|c|}
\hline $\begin{array}{c}\text { Sodium } \\
\text { hydroxide }\end{array}$ & $\begin{array}{c}\text { Potassium } \\
\text { hydroxide }\end{array}$ & $\begin{array}{c}\text { Potassium } \\
\text { methoxide }\end{array}$ & $\begin{array}{c}\text { Sodium } \\
\text { methoxide }\end{array}$ \\
\hline 606.97 & 641.69 & 689.22 & 695.31 \\
\hline
\end{tabular}

Table 4: Land use (ha), fertilizer (kg) and diesel consumption (kg) necessary to biodiesel production.

\begin{tabular}{|l|c|c|c|}
\hline \multicolumn{1}{|c|}{ Catalysts } & Land use (ha) & N fertilizers (kg) & Diesel (kg) \\
\hline Sodium hydroxide & $1.45 \mathrm{E}+00$ & $2.90 \mathrm{E}+02$ & $1.56 \mathrm{E}+02$ \\
\hline Potassium hydroxide & $1.37 \mathrm{E}+00$ & $2.74 \mathrm{E}+02$ & $1.48 \mathrm{E}+02$ \\
\hline Potassium methoxide & $1.28 \mathrm{E}+00$ & $2.55 \mathrm{E}+02$ & $1.38 \mathrm{E}+02$ \\
\hline Sodium methoxide & $1.27 \mathrm{E}+00$ & $2.53 \mathrm{E}+02$ & $1.37 \mathrm{E}+02$ \\
\hline
\end{tabular}


In Table 5 emission gases related to aggregate quantities of diesel fuel used for wine and sunflower production are reported. Emissions are accounted for total diesel quantity production and combustion; diesel quantity for sunflower cultivation will be lower when the catalyst's yield is high, because of the lower land use.

Table 5: $\quad$ Emission gases $(\mathrm{kg})$ from aggregate diesel fuel quantities for wine and sunflower production; $\mathrm{N}_{2} \mathrm{O} \stackrel{\mathrm{f}}{-}$ refers to nitrous oxide from fertilizers used for sunflower cultivation, $\mathrm{N}_{2} \mathrm{O} \stackrel{\mathbf{c}}{\text { refers }}$ to nitrous oxide from diesel fuel.

\begin{tabular}{|l|c|c|c|c|}
\hline & S. hydroxide & P. hydroxide & P. methoxide & S. methoxyde \\
\hline $\mathbf{C O}_{\mathbf{2}}$ & $2.961 \mathrm{E}+03$ & $2.930 \mathrm{E}+03$ & $2.893 \mathrm{E}+03$ & $2.889 \mathrm{E}+03$ \\
\hline $\mathbf{C H}_{\mathbf{4}}$ & $3.670 \mathrm{E}+00$ & $3.632 \mathrm{E}+00$ & $3.586 \mathrm{E}+00$ & $3.580 \mathrm{E}+00$ \\
\hline $\mathbf{N}_{\mathbf{2}} \mathbf{O}^{\mathbf{f}}$ & $3.279 \mathrm{E}+00$ & $3.102 \mathrm{E}+00$ & $2.888 \mathrm{E}+00$ & $2.863 \mathrm{E}+00$ \\
\hline $\mathbf{N}_{\mathbf{2}} \mathbf{O}^{\underline{\mathbf{c}}}$ & $3.062 \mathrm{E}-02$ & $3.030 \mathrm{E}-02$ & $2.991 \mathrm{E}-02$ & $2.987 \mathrm{E}-02$ \\
\hline
\end{tabular}

\subsection{Step c.}

In this phase of our simulation we start from the assumption that the farm system is self sufficient, for wine and sunflower production, by using only biodiesel. In this case all emissions will be related to biodiesel production and combustion. Biodiesel production is divided into two phases:

- $\quad$ agricultural phase, in which the input considered are land use (ha), nitrogen fertilizers $\left(\mathrm{kg} \mathrm{ha}^{-1}\right)$, and their emissions;

- $\quad$ industrial phase, in which we consider all raw materials and processes and related emissions that refer to biodiesel quantity produced;

- combustion refers to all field operations (wine and sunflower production).

The biodiesel quantity necessary for 1 ha of wine and sunflower production has been calculated to be $880 \mathrm{~kg}$; in Table 6 we report land use, $\mathrm{N}$ fertilizer quantity and related emissions as $\mathrm{N}_{2} \mathrm{O}$.

Table 6: $\quad$ Land use, $\mathrm{N}$ fertilizer quantity and related emissions as $\mathrm{N}_{2} \mathrm{O}$.

\begin{tabular}{|l|c|c|c|}
\hline Catalysts & $\begin{array}{c}\text { Land use } \\
\text { (ha) }\end{array}$ & N fertilizer (kg) & $\begin{array}{c}\mathbf{N}_{2} \mathbf{O} \text { emissions } \\
\text { (kg) }\end{array}$ \\
\hline Sodium hydroxide & $1.45 \mathrm{E}+00$ & $2.90 \mathrm{E}+02$ & $3.279 \mathrm{E}+00$ \\
\hline Potassium hydroxide & $1.37 \mathrm{E}+00$ & $2.74 \mathrm{E}+02$ & $3.102 \mathrm{E}+00$ \\
\hline Potassium methoxide & $1.28 \mathrm{E}+00$ & $2.55 \mathrm{E}+02$ & $2.888 \mathrm{E}+00$ \\
\hline Sodyum methoxyde & $1.27 \mathrm{E}+00$ & $2.53 \mathrm{E}+02$ & $2.863 \mathrm{E}+00$ \\
\hline
\end{tabular}

Biodiesel industrial production refers to the transesterification process in which sunflower oil seeds are transformed in methylester and other by-products like glycerine, using catalysts for chemical reactions. Calculations for greenhouse gas emissions are based on the EU Biofit 2000 project, in which 
eight European countries and related research institutes (BLT, Austria; TUD, Denmark; INRA, France; IFEU, Germany; CRES, Greece; CTI, Italy; CLM, The Netherlands; FAT, Switzerland) analyzed production and use of biofuels, with an LCA methodology that take in account all emissions ( $g$ of gases tons ${ }^{-1}$ of biodiesel). So we report our calculations for this phase in Table 7.

Table 7: Emission (kg) from industrial phase for $880 \mathrm{~kg}$ biodiesel transesterification.

\begin{tabular}{|c|c|c|}
\hline $\mathbf{C O}_{\mathbf{2}}$ & $\mathbf{C H}_{\mathbf{4}}$ & $\mathbf{N}_{\mathbf{2}} \mathbf{O}$ \\
\hline $2.04 \mathrm{E}+02$ & $1.70 \mathrm{E}+00$ & $8.36 \mathrm{E}-02$ \\
\hline
\end{tabular}

The last aspects of this step are biodiesel emissions from combustion. Calculations are based on EPA Biodiesel Emissions Database, in which the emission test cycle using different blends of methylester (biodiesel) in different engine types is reported; we selected data referred to pure biodiesel (BD100) and values used in our calculations come out from an average of different tests. Emissions tested by EPA considered $\mathrm{CO}_{2}, \mathrm{CO}, \mathrm{NO}_{\mathrm{x}}$ and THC. THC refers to total hydrocarbons, in which $\mathrm{CH}_{4}$ is included. In Table 8 we show first emissions from biodiesel combustion related to sunflower field operations; BD100 quantities and emissions decrease with the increase of catalysts yield, because of the reduction of land use.

Table 8: $\quad$ Emissions (kg) from biodiesel (BD100) combustion for sunflower field operations.

\begin{tabular}{|l|c|c|c|c|c|}
\hline \multicolumn{1}{|c|}{ Catalysts } & Biodiesel (kg) & $\mathbf{C O}_{\mathbf{2}}$ & $\mathbf{T H C}$ & $\mathbf{C O}$ & $\mathbf{N O}_{\mathbf{x}}$ \\
\hline S. hydroxide & $1.80 \mathrm{E}+02$ & $4.82 \mathrm{E}+02$ & $7.60 \mathrm{E}-02$ & $1.00 \mathrm{E}+00$ & $4.86 \mathrm{E}+00$ \\
\hline P. hydroxide & $1.70 \mathrm{E}+02$ & $4.55 \mathrm{E}+02$ & $7.10 \mathrm{E}-02$ & $9.60 \mathrm{E}-01$ & $4.59 \mathrm{E}+00$ \\
\hline P. methoxide & $1.58 \mathrm{E}+02$ & $4.22 \mathrm{E}+02$ & $6.60 \mathrm{E}-02$ & $8.90 \mathrm{E}-01$ & $4.27 \mathrm{E}+00$ \\
\hline S. methoxide & $1.57 \mathrm{E}+02$ & $4.20 \mathrm{E}+02$ & $6.58 \mathrm{E}-02$ & $8.80 \mathrm{E}-01$ & $4.24 \mathrm{E}+00$ \\
\hline
\end{tabular}

Second we report, in Table 9, biodiesel emissions from wine production.

Table 9: $\quad$ Emissions from biodiesel (BD100) combustion for wine yard field operations.

\begin{tabular}{|c|c|c|c|c|}
\hline Biodiesel (kg) & $\mathbf{C O}_{\mathbf{2}}$ & THC & $\mathbf{C O}$ & NO $_{\mathbf{x}}$ \\
\hline $7.56 \mathrm{E}+02$ & $2.20 \mathrm{E}+03$ & $3.17 \mathrm{E}-02$ & $4.28 \mathrm{E}+00$ & $2.04 \mathrm{E}+01$ \\
\hline
\end{tabular}

\section{Discussion}

In order to explain what are the emission trends from a point of view of emissions at local scale, for vineyard system we summarized the trend of $\mathrm{CO}_{2}$ equivalent emissions $\left(\mathrm{CO}_{2}, \mathrm{CH}_{4}, \mathrm{~N}_{2} \mathrm{O}\right)$ in Fig. 1; at $\mathrm{t} 0$, in which there is only diesel fuel production and consumption emissions, shows a value of $2.47+03 \mathrm{~kg}$; 
at $\mathrm{t} 1$, in which the diesel production and consumption for wine and sunflower production is considered, the value increases until $3.95+03 \mathrm{~kg}$; at $\mathrm{t} 2$, in which only biodiesel is used for all field operations, the value has a little lessening until $3.69+03 \mathrm{~kg}$ (biodiesel production an consumption). In $\mathrm{t} 2-\mathrm{CO}_{2}$ renew, there is the removal of $\mathrm{CO}_{2}$ emissions considered renewable; the difference in petroleum diesel and biodiesel is the time of carbon dioxide fixation; in the case of fossil diesel the process occurred in geological time, while for biodiesel carbon dioxide released in atmosphere is fixed in recent years $[17,18]$ and sunflower cultivation uses it every year. Following this assumption if we remove $\mathrm{CO}_{2}$ emissions from biodiesel combustion, we have a value of $1.05+03 \mathrm{~kg}$.

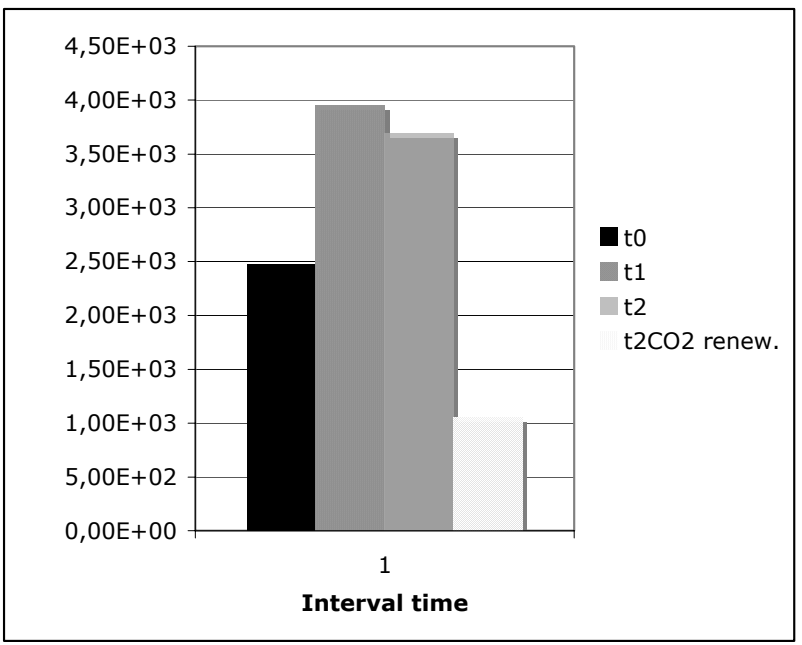

Figure 1: $\quad \mathrm{CO}_{2}$ equivalent emissions for vineyard system.

So the reduction between $\mathrm{t} 0$ and $\mathrm{t} 2-\mathrm{CO}_{2}$ renew for vineyard system is about $57 \%$. The potential of $\mathrm{CO}_{2}$ equivalent reduction for biodiesel production is reported in some works; in 'Evaluation of the comparative energy, global warming and socio-economic costs and benefit of biodiesel', by the Sheffield Hallam University [19], we found a comparison between diesel and biodiesel production; the reduction $\mathrm{GHG}$ emission $\left(\mathrm{kgCO}_{2} \mathrm{eq} / \mathrm{kgbiodiesel}\right)$ for biodiesel is about $-61 \%$. In 'Life cycle inventory of biodiesel and petroleum diesel for use in urban bus' (1998), by the National Renewable Energy Laboratory [20], we found that the life cycle emissions of $\mathrm{CO}_{2}$, on $100 \%$ biodiesel, are $78 \%$ lower than those of petroleum diesel, and this reduction is linked to the carbon recycling by soy cultivation. Emissions from fossil diesel combustion in are calculated using IPCC methodology, module 1 Energy, and emissions from nitrogen fertilizer $\left(\mathrm{N}_{2} \mathrm{O}\right)$ using module 4 Agriculture. We are aware that some authors [21] show that in some conditions the default value used to calculate emissions are not representative, and they can underestimate or overestimate relative emissions values. We are sure that for specific processes at local scale, an appropriate 
approach could be found; however, IPCC methodology is widely used and the only one scientifically accepted, even if it needs improvement.

\section{Conclusion}

There are a large number of comparative studies on the possibilities for diesel and biodiesel use. Our simulation study confirms that biodiesel (BD100) production (agricultural an industrial phases) and combustion are climate friendly. A $57 \%$ reduction in $\mathrm{CO}_{2}$ equivalent emission is possible by using BD100, owing to the renewability of $\mathrm{CO}_{2}$ from its combustion fixed by the growing biomass (sunflower). At scale of Province, emissions reduction comes out from a system self-sufficient from a point of view of fossil fuels use. The results could be lower if farm systems conduction approached to organic farm conduction.

\section{References}

[1] European Parliament, Directive 2003/30/CE, europa.eu.int/eurlex/pri/it/oj/dat/2003/1_123/1_12320030517it00420046.pdf

[2] Bastianoni, S., Marchettini, $\bar{N}$., Ethanol production from biomass: analysis of process efficiency and sustainability. Biomass and Bioenergy, 11(5), pp. 411-418, 1996.

[3] Lapinskienè, A., Martinkus, P., Rèbždaitè, V., Eco-toxicological studies of diesel and biodiesel fuels in aerated soil. Environmental Pollution, 142(3), pp. 432-437, 2006.

[4] Leung, D.Y.C., Koo, B.C.P., Guo, Y., Degradation of biodiesel under different storage conditions. Bioresource Technology, 97(2), pp. 250-256, 2006.

[5] Han, X., Xiaoling, M., Qingyu, W., High quality biodiesel production from a microalga Chlorella protothecoides by heterotrophic growth in fermenters. Journal of Biotechnology, 126(4), pp. 499-507, 2006.

[6] Aresta, M., Dibenedetto, A., Carone, M., Colonna, T., Fragale, C., Production of biodisel from macroalgae by supercritical $\mathrm{CO} 2$ extraction and thermochemical liquefaction. Environment Chemical Letter, 3, pp. 136-139, 2005.

[7] Meher, L.C., Vidya Sagar, D., Naik, S.N., Technical aspects of biodiesel production by transesterification-a review, Renewable and Sustainable Energy Reviews, 10, pp. 248-268, 2006.

[8] Beyond Petroleum. BP Annual Review 2005, http://www.bp.com/

[9] Energy Information Administration (EIA). International Energy Annual 2003, http://www.eia.doe.gov/pub/international

[10] Environmental Design of Industrial Products (EDIP Database), 2006.

[11] Revised IPCC. Guidelines for national green house gas inventory, volumes 1-3. Intergovernmental Panel on Climate Change, London, 1996. 
[12] Riva G., Calzoni J., Panvini A., BIOFIT. Bioenergy for Europe: Which one fits best? A comparative analysis for the Community, 2000. http://www.cti2000.it

[13] EPA Biodiesel Emission Database (EPA), 2001. http://www.epa.gov/OMS/models/biodsl

[14] Vicente, G., Martinez, M., Aracil, J., Integrated biodiesel production: a comparison of different homogeneous catalysts systems. Bioresource Technology, 92(3), pp. 297-305, 2004.

[15] Quinto Censimento dell'Agricoltura, 2000. www.istat.it/censimenti /agricoltura/

[16] Kallivroussis, L., Natsis, A., Papadakis, G., The energy balance of sunflower production for biodiesel in Greece. Biosystems Engineering, 81(3), pp. 347-354, 2002.

[17] Peterson, C. L., Hustrulid, T., Carbon cycle for rapeseed oil biodiesel fuels. Fuel and Energy Abstracts, 39(5), pp. 363, 1998.

[18] Tiezzi, E., The end of time, WIT Press, Southampton, pp. 61-62, 2002.

[19] Mortimer N.D, Cormack P., Elsayed M.A., Horne R.E., Evaluation of the comparative energy, global warming and socio-economic costs and benefits of biodiesel. Final report, Sheffield Hallam University, 2003. http://www.defra.gov.uk/farm/crops/industrial/whatwasnew.htm

[20] Life cycle inventory of biodiesel and petroleum diesel for use in urban buses. Final report, 1998. http://www.nrel.gov/docs/legosti/fy98 /24089.pdf

[21] Brown, L., Brown, S.A., Jarvis, S. C., Syed, B., Goulding, K.W.T., Phillips, V.R., Sneath, R.W., Pain, B.F., An inventory of nitrous oxide emissions from agriculture in the UK using the IPCC methodology: emission estimate, uncertainty and sensitivity analysis. Atmospheric Environment, 35(8), pp.1439-1449, 2001. 